\title{
Cataract extraction and intraocular lens implantation in children with uveitis
}

\author{
Anna Lundvall, Charlotta Zetterström
}

\begin{abstract}
Aim-To evaluate the long term results of cataract surgery with intraocular lens implantation (IOL) in children with uveitis.

Methods-The study included 10 eyes in seven children (age 3.5-10 years, mean 6.5 years). The cataract surgery included capsulorhexis of the anterior and the posterior capsule, anterior vitrectomy in some eyes, and implantation of a heparin surface modified (HSM) poly(methyl methacrylate) (PMMA) IOL into the capsular bag.

Results-Follow up periods ranged from 1 to 5 years. Best corrected visual acuity after surgery reached 20/50-20/20 in all but two eyes. Opacities or membranes requiring reoperation developed in seven eyes. Glaucoma developed in three eyes after the cataract operation.

Conclusion-These results suggest that implantation of a HSM PMMA IOL is an alternative to correct aphakia also in children with uveitis.
\end{abstract}

(Br F Ophthalmol 2000;84:791-793)

Cataract surgery with intraocular lens (IOL) implantation has been fully accepted in children over the age of 1-2 years since several years. ${ }^{1-6}$ The treatment of cataract as a complication of uveitis is controversial, particularly in children. ${ }^{78}$ Cataract extraction has been assumed to activate the inflammatory process and IOL implantation has been considered to increase the rate of serious complications in eyes with uveitis. ${ }^{9}$ In the past decade, however, several studies have been reported indicating that selected adult uveitis patients can benefit from IOL implantation. ${ }^{10-15}$

Disregarding single cases, reports of cataract surgery with IOL implantation in children with uveitis are lacking. In this report we describe the results of heparin coated poly(methyl methacrylate) (PMMA) IOL implantation in 10 eyes in seven children with uveitis and cataract.

28 January 2000

Table 1 Preoperative characteristics

\begin{tabular}{llllll}
\hline Patient No & Sex & Eye & $\begin{array}{l}\text { Age (years) at } \\
\text { surgery }\end{array}$ & $\begin{array}{l}\text { Age (years) at } \\
\text { diagnosis of uveitis }\end{array}$ & Glaucoma \\
\hline 1 & F & RE LE & 67.5 & 3 & +- \\
2 & F & RE & 4 & 4 & - \\
3 & M & LE & 7.5 & 4 & - \\
4 & F & LE & 3.5 & 2.5 & + \\
5 & F & RE & 10 & 8 & -- \\
6 & M & RE LE & 8.59 & 7 & +- \\
7 & F & RE LE & 4.55 & 3 & + \\
\hline
\end{tabular}

\section{Patients and methods}

Seven children have undergone cataract surgery with IOL implantation in 10 eyes. They were 3.5 to 10 years old (mean age 6.5 years) at the cataract operation (Table 1 ).

The uveitis was typical of that associated with juvenile rheumatoid arthritis (JRA); all eyes had band keratopathy and extensive posterior synechiae. All children had a positive test for antinuclear antibody but only three had mild joint involvement, which had been symptomatic before uveitis diagnosis in one child only. In no child were there signs of other systemic diseases.

The uveitis had been under control for several weeks at the time of surgery. Corticosteroids orally, in doses of $20-40 \mathrm{mg} /$ day, and topically were used before and after surgery. Some patients were taking systemic methotrexate and corticosteroid treatment for long before surgery and received lower doses of steroids preoperatively. In one patient (patient 4), however, neither oral steroid treatment nor methotrexate was given before surgery. Topical corticosteroids were adjusted for each eye on an individual basis. Postoperatively, dexamethasone was given eight times a day and a combination of cyclopentolate and phenylephrine three times a day followed by a slow taper on an individual basis.

One surgeon (CZ) performed all surgery. A $3.2 \mathrm{~mm}$ scleral pocket incision was used. Posterior synechiae were lysed under viscoelastic control (Healon GV $14 \mathrm{mg} / \mathrm{ml}$ ) and an anterior capsulorhexis was performed. Iris hooks were used to enlarge small pupils. After hydrodissection, mechanised irrigation/ aspiration of the nucleus and cortex was carried out. Posterior capsulorhexis was performed and the wound enlarged to the diameter of the IOL optic for implantation of a heparin surface modified (HSM) PMMA IOL (Pharmacia Upjohn type 808 C, or 809 C) in the capsular bag. Dry anterior vitrectomy was performed in five out of the 10 eyes.

\section{Results}

Four patients underwent unilateral surgery and three patients had bilateral surgery. All but one had severe uveitis with complications at the time of diagnosis. The mean follow up after cataract extraction was 28 months (Table 2).

Visual acuity (VA) improved postoperatively in all eyes but one and best corrected VA at last check was $20 / 50-20 / 20$ in all but two eyes. In patient 1 , the low VA $(20 / 80)$ of the left eye was a consequence of glaucoma.

In one girl (patient 4) the vision was not improved. She had five reoperations for secondary membranes and the vision was reduced 
Table 2 Results of surgery, glaucoma development, and reoperations

\begin{tabular}{|c|c|c|c|c|c|c|c|}
\hline $\begin{array}{l}\text { Patient } \\
\text { noleye }\end{array}$ & $\begin{array}{l}\text { Follow up } \\
\text { (months) }\end{array}$ & $\begin{array}{l}\text { VA before } \\
\text { surgery }\end{array}$ & $\begin{array}{l}\text { VA at follow } \\
\text { up }\end{array}$ & $\begin{array}{l}\text { Glaucoma debut in } \\
\text { relation to cataract } \\
\text { surgery }\end{array}$ & $\begin{array}{l}\text { Pressure lowering surgery, } \\
\text { interval in relation to IOL } \\
\text { implantation }\end{array}$ & $\begin{array}{l}\text { Dry anterior } \\
\text { vitrectomy at } \\
\text { cataract surgery }\end{array}$ & $\begin{array}{l}\text { Additional surgery, period after } \\
\text { cataract surgery }\end{array}$ \\
\hline $1 / \mathrm{RE}$ & 62 & HM & $20 / 20$ & Before & Peripheral iridectomy, & No & Membrane, 16 months \\
\hline LE & 46 & $\mathrm{HM}$ & $20 / 80$ & After 14 months & $\begin{array}{l}\text { trabeculectomy (before) } \\
\text { Trabeculectomy, } 20 \text { months } \\
\text { Moltenoimplant, } 45 \text { months }\end{array}$ & No & Membrane Nd:YAG, 14 months \\
\hline 2/RE & 33 & $\mathrm{CF}$ & $20 / 40$ & After 3 months & $\begin{array}{l}\text { Laser iridotomy, } 3 \text { months } \\
\text { Moltenoimplant, } 33 \text { months }\end{array}$ & No & $\begin{array}{l}\text { Membrane Nd:YAG, } 7 \text { months } \\
\text { Membrane, } 8 \text { months }\end{array}$ \\
\hline $3 / \mathrm{LE}$ & 29 & $20 / 200$ & $20 / 40$ & No glaucoma & - & No & After-cataract, 29 months \\
\hline 4/LE & 27 & $\mathrm{CF}$ & $\mathrm{HM}$ & After 12 months & - & Yes & $\begin{array}{l}\text { Membrane, } 5 \text { times during the first } \\
12 \text { months } \\
\text { Excimer of band keratopathy twice }\end{array}$ \\
\hline 5/RE & 22 & LP & $20 / 22$ & Before & - & No & - \\
\hline 6/RE & 20 & $\mathrm{CF}$ & $20 / 30$ & No glaucoma & - & Yes & - \\
\hline $\mathrm{LE}$ & 14 & HM & $20 / 50$ & No glaucoma & - & Yes & - \\
\hline 7/RE & 17 & $\mathrm{CF}$ & $20 / 25$ & Before & - & Yes & Membrane, 9 months \\
\hline LE & 12 & $20 / 200$ & $20 / 25$ & No glaucoma & - & Yes & Membrane, Nd:YAG, 4 months \\
\hline
\end{tabular}

$\mathrm{VA}=$ Snellen visual acuity $\mathrm{CF}=$ counting fingers; $\mathrm{HM}=$ hand movements; $\mathrm{LP}=$ light perception.

to hand movements. She also developed glaucoma, macular oedema and severe band keratopathy. Unfortunately, her other eye also developed uveitis and was later operated with pars plana lensectomy and vitrectomy without IOL implantation. That eye also has a low VA (20/125) and nystagmus. Macular oedema, glaucomatous damage, and band keratopathy cause the poor visual outcome of that eye.

Glaucoma was diagnosed in three eyes before cataract surgery and glaucoma developed in three eyes 3-14 months after IOL implantation. If medical therapy was not effective, IOP control was achieved with trabeculectomy and Molteno implant when required.

Posterior capsular opacification (PCO) and secondary membranes developed in seven out of the 10 eyes and reoperation was required; two needed only Nd:YAG laser. Only one additional operation was required, except for patient 2 , who had two operations, and patient 4 , who had five operations.

At last check all patients were taking anti-inflammatory treatment but one showed signs of active uveitis.

\section{Discussion}

In the present series of seven children with advanced uveitis complicated by cataract, a best corrected visual acuity of $20 / 40$ or better was attained in seven out of 10 eyes. Systemic studies of IOL implantation in children with uveitis are lacking but the visual results of IOL implantation in this small series of children are comparable with those reported in adults with uveitis. ${ }^{11-14} 16$

Some authors have recommended pars plana vitrectomy and lensectomy with complete excision of the posterior capsule, with similar results as in the present study. ${ }^{817} 18$ However, this technique commits the patient to a lifelong dependence on aphakic correction.

The operation was not performed until the uveitis had been quiescent for some weeks and recurrences did not occur perioperatively. Besides topical steroids given to all perioperatively, systemic steroids were also given to all but one (patient 4), which might have been of importance for the negative outcome in this patient.
Although the diagnostic criteria for JRA according to ILAR were not met in the present patients-only three had mild arthritis symptoms - the uveitis was of JRA type and all children had antinuclear antibodies. It is not uncommon that the uveitis antedates the arthritis and it has been reported that the visual prognosis is poor in these cases, probably due to delay in the diagnosis of the uveitis. ${ }^{9}$

Apart from single patients with JRA associated uveitis included in the different published series treated with IOL implantation there is only one study addressing IOL in this type of uveitis. This study comprised seven patients with JRA (eight eyes). ${ }^{10}$ A visual acuity of $20 / 40$ or better was attained in all eyes; however, only two children under the age of 10 years were included. Complications in children with uveitis treated with IOL have been reported ${ }^{10}{ }^{19}$ and in some cases removal of the IOL has been necessary. ${ }^{20}$ However, the surgery was not standardised, different IOLs were used, and the surgery was performed in several hospitals.

Membrane formation and posterior capsule opacification were common complications in our series but did not constitute a serious problem except in one patient requiring several reoperations and developing glaucoma and poor VA. Membranes also develop in uveitic eyes not undergoing surgery. ${ }^{21}$

IOL implantation has been reported to decrease the PCO tendency in adults, ${ }^{22}$ and in animal experiments. ${ }^{23} 24 \mathrm{~A}$ decreased tendency to recurrences and inflammation in uveitis after IOL implantation has also been reported. ${ }^{25}$ It is possible that anterior vitrectomy diminishes $\mathrm{PCO}$ in children operated for cataract $^{26}$; of the three eyes not developing membrane formation in the present series, two had dry anterior vitrectomy at cataract surgery.

Glaucoma is a common complication of JRA associated uveitis ${ }^{27} 28$ and in this series glaucoma had developed preoperatively in three eyes. Glaucoma evolved in three eyes 3-14 months after surgery. Two of the latter have successfully received a Molteno implant. The follow up period is short so it is possible that glaucoma may develop in more eyes in the future. 


\section{Conclusion}

Though negative experiences with IOL in children with uveitis have been reported in many occasional cases, the present results indicate that cataract extraction with a heparin coated IOL implantation is an alternative in children with uveitis, provided that the uveitis is inactive and treated with steroids topically and systemically.

Presented in part at the XII Congress of the European Society of Ophthalmology, Stockholm, Sweden, June 1999.

The authors have no proprietary interests in the products mentioned in the article.

1 Simons BD, Siatkowski RM, Schiffman JC, et al. Surgical technique, visual outcome, and complications of pediatric intraocular lens implantation. $\mathcal{F}$ Pediatr Ophthalmol Strabismus 1999:36:118-24.

2 Gimbel HV, Basti S, Ferensowicz M, et al. Results of bilateral cataract extraction with posterior chamber intraocular lens implantation in children. Ophthalmology 1997;104 1737-43.

3 Hamill MB, Koch DD. Pediatric cataracts. Curr Opin Ophthalmol 1999;10:4-9.

4 Zetterstrom C, Kugelberg U, Oscarson C. Cataract surgery in children with capsulorhexis of anterior and posterio capsules and heparin-surface-modified intraocular lenses. $F$ Cataract Refract Surg 1994;20:599-601.

5 Vasavada A, Chauhan H. Intraocular lens implantation in infants with congenital cataracts. F Cataract Refract Surg 1994;20:592-8.

6 Lesueur LC, Arne JL, Chapotot EC, et al. Visual outcome after paediatric cataract surgery: is age a major factor? $\mathrm{Br} \mathcal{F}$ after paediatric cataract surgery: is age a major factor? $B r f$

7 Foster CS, Fong LP, Singh G. Cataract surgery and intraocular lens implantation in patients with uveitis. Ophintraocular lens implantation
thalmology 1989;96:281-8.

8 Holland GN. Intraocular lens implantation in patients with juvenile rheumatoid arthritis-associated uveitis: an unresolved management issue. Am f Ophthalmol 1996;122:2557.

9 Kanski JJ. Juvenile arthritis and uveitis. Surv Ophthalmol 1990;34:253-67.

10 Probst LE, Holland EJ. Intraocular lens implantation in patients with juvenile rheumatoid arthritis. Am $\mathcal{F}$ Ophthalmol 1996;122:161-70.

11 Chung Y, Yeh T. Intraocular lens implantation following extracapsular cataract extraction in uveitis. Ophthalmic Surg 1990;21:272-6.
12 Foster RE, Lowder CY, Meisler DM, et al. Extracapsular cataract extraction and posterior chamber intraocular lens mplantation in uveitis patients. Ophthalmology 1992;99: 1234-41

13 Pleyer U, Pawlikowska J, Zierhut M, et al. Clinical aspects, follow-up and results of cataract extraction in uveitis. $O p h-$ thalmologe 1992;89:295-300.

14 Dana M, Chatzistefanou K, Schaumberg D, et al. Posterior capsule opacification after cataract surgery in patients with uveitis. Ophthalmology 1997;104:1387-93.

15 Lam DS, Law RW, Wong AK. Phacoemulsification, primary posterior capsulorhexis, and capsular intraocular lens implantation for uveitic cataract. F Cataract Refract Surg 1998;24:1111-8.

16 Tessler HH, Farber MD. Intraocular lens implantation versus no intraocular lens implantation in patients with chronic iridocyclitis and pars planitis. A randomized prospective study. Ophthalmology 1993;100:1206-9

17 Flynn HW Jr, Davis JL, Culbertson WW. Pars plana lensectomy and vitrectomy for complicated cataracts in juvenile rheumatoid arthritis. Ophthalmology 1988;95:1114-9.

18 Foster CS, Barrett F. Cataract development and cataract surgery in patients with juvenile rheumatoid arthritisassociated iridocyclitis. Ophthalmology 1993;100:809-17.

19 Haberle H, Velhagen KH, Pleyer U. Pseudophakia in children with juvenile arthritis. Ophthalmologe 1998;95: 823-7.

20 Foster CS, Stavrou P, Zafirakis P, et al. Intraocular lens removal in patients with uveitis. Am $f$ Ophthalmol 1999;128:31-7.

21 Nussenblatt RB, Palestine AG. Uveitis. Fundamentals and clinical practice. Chicago: Year Book Medical Publishers, 1989

22 Nishi O. Incidence of posterior capsule opacification in eyes with and without posterior chamber intraocular lenses. F Cataract Refract Surg 1986;12:519-22.

23 Zetterstrom C, Kugelberg U, Lundgren B, et al. Aftercataract formation in newborn rabbits implanted with intraocular lenses. F Cataract Refract Surg 1996;22:85-8.

24 Kugelberg U, Zetterstrom C, Lundgren B, et al. Ocular growth in newborn rabbit eyes implanted with a poly(me-
thyl methacrylate) or silicone intraocular lens. f Cataract Refract Surg 1997;23(Suppl 1):629-34.

25 Tran VT, Guex-Crosier Y, Herbort CP. Effect of cataract surgery with intraocular lens implantation on inflammation in chronic uveitis: a longitudinal laser flare photometry in chronic uveitis: a longitudinal laser

26 Vasavada A, Desai J. Primary posterior capsulorhexis with and without anterior vitrectomy in congenital cataracts. $\mathcal{F}$ Cataract Refract Surg 1997;23(Suppl 1):645-51.

27 Wolf MD, Lichter PR, Ragsdale CG. Prognostic factors in the uveitis of juvenile rheumatoid arthritis. Ophthalmology 1987;94:1242-8.

28 Kanski JJ. Lensectomy for complicated cataract in juvenile chronic iridocyclitis. Br $\mathcal{F}$ Ophthalmol 1992;76:72-5. 